\title{
Fluticasone furoate verses fluticasone propionate: a comparative study by assessment of nasal mucociliary clearance time on patients with allergic rhinitis
}

\author{
Vimal Nambiar*, Sheetal Rai, Gangadhar Somayaji K. S.
}

Department of ENT, Yenepoya Medical College, Deralakatte, Mangalore 575018, Karnataka, India

Received: 18 December 2015

Accepted: 27 December 2015

\section{*Correspondence:}

Dr. Vimal Nambiar,

E-mail: drvimalnambiar@gmail.com

Copyright: (C) the author(s), publisher and licensee Medip Academy. This is an open-access article distributed under the terms of the Creative Commons Attribution Non-Commercial License, which permits unrestricted non-commercial use, distribution, and reproduction in any medium, provided the original work is properly cited.

\begin{abstract}
Background: Allergic diseases in India have been on an uprising trend. 3.5\% of the population in INDIA is suffering from Allergic Rhinitis. This study aims to compare the effectiveness of two commonly used intranasal steroidsFluticasone Furoate (FF) and Fluticasone Propionate (FP) using the nasal mucociliary clearance time (NMCT).

Methods: We conducted a prospective study on 70 patients. 35 each on FF and FP. Pretreatment and Post treatment Nasal was assessed by Saccharin Test. Patients were then put on either FF or FP for a period of one month.

Results: Average improvement of NMCT post treatment with steroids sprays is 2-3 minutes.(Average Pretreatment time is 17.92 and Average Post treatment time 15.55 minutes).

Conclusion: Both drugs are equally efficacious and well tolerated by the patients. Compliance of Fluticasone Furoate was better because of its once daily dosage. Disadvantages of FP are its twice daily dosage and after taste.
\end{abstract}

Keywords: Allergic rhinitis, Nasal mucociliary clearance time, Fluticasone furoate, Fluticasone propionate

\section{INTRODUCTION}

Allergic rhinitis (AR) is an IgE mediated hypersensitivity disease of the mucous membrane of the nasal airway characterized by sneezing, itching, watery nasal discharge and sensation of nasal obstruction. The mucosal lining of the nose is continuous with the paranasal sinus which may get involved. Associated allergic conjunctivitis and bronchial asthma may occur. Allergic rhinitis occurs to atopic individuals that are exposed to aero-allergens with a quoted prevalence rate varying widely between $0.9 \%$ and $39.7 \%$. $^{1}$

Depending on the duration of exposure to allergens and the duration of symptoms, AR has been classified as perennial AR (PAR) or seasonal AR (SAR).,

Allergic reactions occur when a person's immune system reacts abnormally to normally harmless substances, present in the environment. Allergic Rhinitis is formally called type I (or immediate) hypersensitivity and is one of the four or more forms of hypersensitivity. The burden of allergic diseases in India has been on an uprising trend in terms of prevalence as well as severity. These allergic diseases comprise of asthma, rhinitis, anaphylaxis, drug, food and insect allergy, eczema, urticaria and angioedema. Approximately $20 \%$ to $30 \%$ of total population suffers from at least one of these allergic diseases in India. Allergic rhinitis is another major allergic disease which frequently is ignored both by the patients and doctors. It is one of the important global problems and is increasing in prevalence. Allergic rhinitis (manifested as "recurrent coryza") was found to be prevalent in $3.5 \%$ of the population in INDIA in a multi centric study by Prasad R et al. ${ }^{4}$

Several classes of medications are available to treat AR; however, only intranasal corticosteroids (INS) have proven anti-inflammatory activity against 
pathophysiological aspects of both early and late-phase allergic reactions and have a broad spectrum of efficacy for the range of nasal symptoms including congestion, rhinorrhea, sneezing, and nasal itching. Fluticasone Furoate and Fluticasone Propionate is a novel enhancedaffinity glucocorticoid administered to the nose in metered spray device. This ergonomically designed drug delivery system allows for improved handling and comfort during use and shows consistent dose-delivery characteristics across a wide patient population. Preclinical study in human lung glucocorticoid receptors has shown that the relative receptor affinity of Fluticasone Furoate (FF) exceeds that of clinically available corticosteroids, including Fluticasone Propionate (FP) and Mometasone Furoate. Fluticasone Furoate also has potent pharmacologic actions including acceleration of transcription via the glucocorticoid response element, inhibition of activation of transcription factors including $\mathrm{NFkB}$, and inhibition of antigeninduced eosinophil infiltration in lungs in sensitized rats. These results may contribute to prolonged duration and highly efficacious profile for $\mathrm{FF}$ as a topical treatment for AR. The clinical benefits of FFNS in reducing the nasal symptoms of AR have been shown in clinical studies in the United States, Europe, and Japan. ${ }^{5}$

Allergic rhinitis has a significant physical and economic impact on the patient. However, rhinorrhea, a prominent feature of allergic rhinitis has a social impact also as the sufferer has to use handkerchief all the time. Nasal secretions humidify the inspired air however the excess secretions in allergic rhinitis are taken care by nasal mucociliary clearance. ${ }^{6}$

The present study aims to study the effect of intranasal steroids on nasal mucociliary clearance in patients with allergic rhinitis and also to compare the effectiveness of two commonly used intranasal steroids- Fluticasone Furoate and Fluticasone Propionate using the nasal mucociliary clearance time.

\section{METHODS}

The present study was carried out in a tertiary care hospital with the approval of the Ethical committee. Relevant clinical data (demographic- age, sex, place, occupation) including history was obtained from the patient. A detailed clinical examination was performed and relevant investigations conducted. Patients with complaints of nasal obstruction, persistent watery rhinorrhea, sneezing and itching were selected. A total of 70 patients were studied. The patients were grouped into two groups of 35 each. One group treated with Fluticasone Furoate metered spray (once daily - 55mcg) and the other group was treated with Fluticasone Propionate metered spray (twice daily $200 \mathrm{mcg} /$ day) both for a period of one month. The mucociliary clearance time is tested before and after one month of treatment by using Saccharin.

\section{Symptom scores for subjective nasal obstruction, watery rhinorrhea and sneezing}

The following symptoms were recorded for each of the groups to determine a symptom score: nasal obstruction, rhinorrhea and sneezing. Means of the degree of subjective grade measuring complaints was evaluated using a numerical scoring system, as follows: Grade 0, Grade 1, Grade 2 and grade 3.

\section{Saccharin time measurement for measuring the nasal mucociliary clearance}

The Saccharin time measurement was performed without the use of a topical anesthetic agent to preclude it having any effect on ciliary movement. Saccharin granules were each 1 to $2 \mathrm{~mm}$ in diameter and weight 5 to $8 \mathrm{mg}$. With the patient in sitting position, a saccharin granule was placed on the frontal edge of the inferior turbinate. The time at which the subject reports a sweet taste after the saccharin application was recorded in minutes. After one month of treatment with Fluticasone Furoate or Fluticasone Propionate nasal spray the patients were called for a repeat Saccharin Test. The pre and post treatment Saccharin Test time was then compared.

\section{RESULTS}

Out of the 70 patients who underwent the study, 35 patients were treated with Fluticasone Furoate and 35 patients with Fluticasone Propionate. The patients were randomly assigned this medication for a period of one month duration. Patients underwent a Nasal mucociliary Clearance Test prior to treatment and one month post treatment. Patients were also scored (nasal score) based on their symptoms prior to treatment and one month post treatment.

\section{Nasal mucociliary clearance time (NMCT)}

The average pretreatment nasal mucociliary clearance time of the 70 patients who underwent the study was 17.92 minutes and the average post treatment time was 15.55 minutes. The patients who were put on Fluticasone Furoate had an average pretreatment NMCT of 17.88 minutes and post treatment NMCT of 15.51 minutes. The patients who were on Fluticasone Propionate had an average pretreatment NMCT of 17.97 minutes and a post treatment NMCT of 15.60 minutes. All patients showed an improvement in nasal mucociliary clearance time post treatment ranging from 2-3 minutes which put them in the physiological accepted range of 12-16 minutes.

\section{Nasal score pre treatment}

$42.9 \%$ of the patients on Fluticasone Furoate and $25.7 \%$ of patients on Fluticasone Propionate had a symptom score of 2 prior to treatment.57.1\% of the Fluticasone Furoate group and $74.3 \%$ of Fluticasone Propionate group scored 3 (Figure 1). 


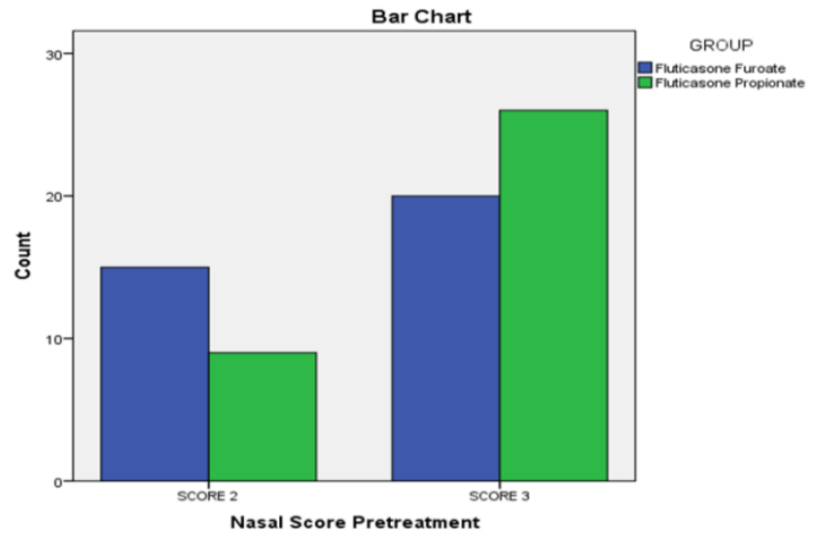

Figure 1 (a): Pre treatment.

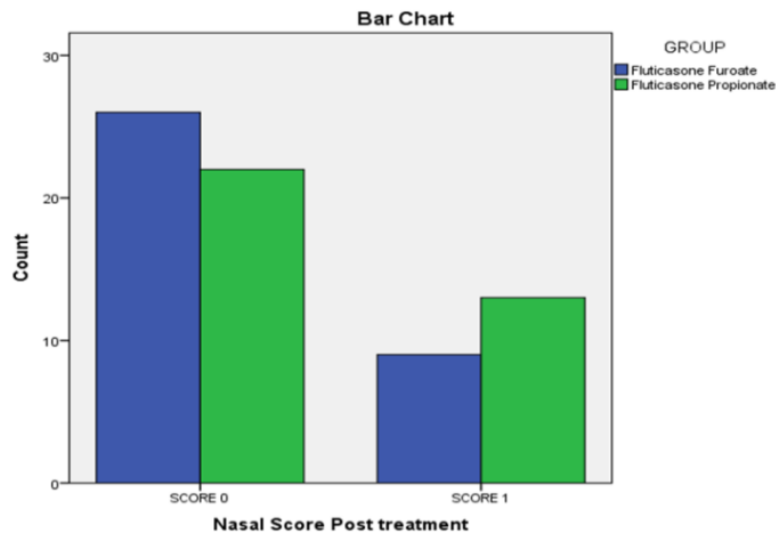

Figure 1 (b): Post treatment.

Figure 1: Graph showing nasal score pre and post treatment.

\section{Nasal score post treatment}

74.3\% of the patients on Fluticasone Furoate and $62.9 \%$ of the patients on Fluticasone Propionate had a symptom score of 0 post one month of treatment.

$25.7 \%$ of the patients on Fluticasone Furoate and $37.1 \%$ of the patients on Fluticasone Propionate had a symptom score of 1 post one month of treatment (Table 1).

Table 1: Nasal score post treatment.

\begin{tabular}{|c|c|c|c|c|c|}
\hline \multicolumn{6}{|c|}{ Crosstab } \\
\hline & & \multicolumn{3}{|c|}{ Group } & \multirow[b]{2}{*}{ Tota } \\
\hline & & & $\begin{array}{l}\text { Fluticas } \\
\text { one } \\
\text { Furoate }\end{array}$ & $\begin{array}{l}\text { Flutic } \\
\text { asone } \\
\text { Propi } \\
\text { onate }\end{array}$ & \\
\hline \multirow{4}{*}{$\begin{array}{l}\text { Nasal } \\
\text { Score } \\
\text { Post } \\
\text { treat } \\
\text { ment }\end{array}$} & \multirow[b]{2}{*}{$\begin{array}{l}\text { score } \\
0\end{array}$} & Count & 26 & 22 & 48 \\
\hline & & $\begin{array}{l}\% \\
\text { within } \\
\text { group }\end{array}$ & $74.3 \%$ & $62.9 \%$ & $\begin{array}{l}68.6 \\
\%\end{array}$ \\
\hline & \multirow[b]{2}{*}{$\begin{array}{l}\text { score } \\
1\end{array}$} & Count & 9 & 13 & 22 \\
\hline & & $\begin{array}{l}\% \\
\text { within } \\
\text { group }\end{array}$ & $25.7 \%$ & $37.1 \%$ & $\begin{array}{l}31.4 \\
\%\end{array}$ \\
\hline \multirow[b]{2}{*}{ Total } & & Count & 35 & 35 & 70 \\
\hline & & $\begin{array}{l}\% \\
\text { within } \\
\text { group }\end{array}$ & $\begin{array}{l}100.0 \\
\%\end{array}$ & $\begin{array}{l}100.0 \\
\%\end{array}$ & $\begin{array}{l}100.0 \\
\%\end{array}$ \\
\hline
\end{tabular}

Comparison of the nasal score pretreatment and post treatment shows that both drugs are of almost equal efficacy in treatment of allergic rhinitis with a statistical improvement in nasal symptom score between pre and post treatment (Table 2).
26 patients on Fluticasone Furoate and 22 patients on Fluticasone Propionate group reached a symptom score of 0 post treatment. Both these drugs show significant improvement in symptom score.

\section{Patient satisfaction}

In our study after one month of treatment with both Fluticasone Furoate and Fluticasone Propionate all patients had relief of most symptoms. Some patients though had certain complaints mainly dryness, crusting, bad taste and pain.

22.9\% of the patients on Fluticasone Furoate complained of dryness compared to $34.3 \%$ of the patients on Fluticasone Propionate. $8.6 \%$ of the patients on Fluticasone Furoate complained of crusting compared to the $22.9 \%$ of the patients in the Fluticasone Propionate. $17.1 \%$ of patients complained of bad taste post treatment with Fluticasone Propionate but none complained about any after taste with Fluticasone Furoate. $11.4 \%$ of the on Fluticasone Furoate nasal spray and $14.3 \%$ on Fluticasone Propionate nasal spray complained of pain on delivering the spray. None of the above complaints were of significance as only a small number of patients experienced these problems (Table 3 ).

\section{DISCUSSION}

The present study was done to establish the efficacy of intranasal steroid sprays as well as to compare the efficacy between Fluticasone Furoate and Fluticasone Propionate. Though both Fluticasone Furoate and Fluticasone Propionate are efficacious in the treatment of Allergic Rhinitis we found that there is no significant difference in the efficacy between the two drugs. Both drugs gave significant relief to the patient and improved their quality of life. 
Table 2: Nasal score pretreatment and nasal score post treatment. Cross tabulation.

\begin{tabular}{|c|c|c|c|c|c|c|}
\hline \multicolumn{4}{|l|}{ Group } & \multicolumn{2}{|c|}{ Nasal Score Post treatment } & \multirow{2}{*}{ Total } \\
\hline & & & & Score 0 & Score 1 & \\
\hline \multirow{6}{*}{$\begin{array}{l}\text { Fluticasone } \\
\text { Furoate }\end{array}$} & \multirow{4}{*}{$\begin{array}{l}\text { Nasal Score } \\
\text { Pretreatment }\end{array}$} & \multirow[b]{2}{*}{ Score 2} & Count & 12 & 3 & 15 \\
\hline & & & $\begin{array}{l}\% \text { within Nasal Score } \\
\text { Post treatment }\end{array}$ & $46.2 \%$ & $33.3 \%$ & $42.9 \%$ \\
\hline & & \multirow[b]{2}{*}{ Score 3} & Count & 14 & 6 & 20 \\
\hline & & & $\begin{array}{l}\% \text { within Nasal Score } \\
\text { Post treatment }\end{array}$ & $53.8 \%$ & $66.7 \%$ & $57.1 \%$ \\
\hline & \multirow[b]{2}{*}{ Total } & & Count & 26 & 9 & 35 \\
\hline & & & $\begin{array}{l}\% \text { within Nasal Score } \\
\text { Post treatment }\end{array}$ & $100.0 \%$ & $100.0 \%$ & $100.0 \%$ \\
\hline \multirow{6}{*}{$\begin{array}{l}\text { Fluticasone } \\
\text { Propionate }\end{array}$} & \multirow{4}{*}{$\begin{array}{l}\text { Nasal Score } \\
\text { Pretreatment }\end{array}$} & \multirow[b]{2}{*}{ Score 2} & Count & 6 & 3 & 9 \\
\hline & & & $\begin{array}{l}\% \text { within Nasal Score } \\
\text { Post treatment }\end{array}$ & $27.3 \%$ & $23.1 \%$ & $25.7 \%$ \\
\hline & & \multirow[b]{2}{*}{ Score 3} & Count & 16 & 10 & 26 \\
\hline & & & $\begin{array}{l}\% \text { within Nasal Score } \\
\text { Post treatment }\end{array}$ & $72.7 \%$ & $76.9 \%$ & $74.3 \%$ \\
\hline & \multirow[b]{2}{*}{ Total } & & Count & 22 & 13 & 35 \\
\hline & & & $\begin{array}{l}\% \text { within Nasal Score } \\
\text { Post treatment }\end{array}$ & $100.0 \%$ & $100.0 \%$ & $100.0 \%$ \\
\hline
\end{tabular}

Table 3: Comparison of post treatment complaints.

\begin{tabular}{|c|c|c|c|c|c|}
\hline & & \multicolumn{4}{|l|}{ Group } \\
\hline & & \multicolumn{2}{|c|}{ Fluticasone Furoate } & \multicolumn{2}{|c|}{ Fluticasone Propionate } \\
\hline & & Count & Column N \% & Count & Column N \% \\
\hline \multirow{2}{*}{ Sex } & $\mathrm{F}$ & 14 & $40.0 \%$ & 10 & $28.6 \%$ \\
\hline & M & 21 & $60.0 \%$ & 25 & $71.4 \%$ \\
\hline \multirow{4}{*}{ Nasal score pre treatment } & Score 0 & 0 & $0.0 \%$ & 0 & $0.0 \%$ \\
\hline & Score 1 & 0 & $0.0 \%$ & 0 & $0.0 \%$ \\
\hline & Score 2 & 15 & $42.9 \%$ & 9 & $25.7 \%$ \\
\hline & Score 3 & 20 & $57.1 \%$ & 26 & $74.3 \%$ \\
\hline \multirow{4}{*}{ Nasal score post treatment } & Score 0 & 26 & $74.3 \%$ & 22 & $62.9 \%$ \\
\hline & Score 1 & 9 & $25.7 \%$ & 13 & $37.1 \%$ \\
\hline & Score 2 & 0 & $0.0 \%$ & 0 & $0.0 \%$ \\
\hline & Score 3 & 0 & $0.0 \%$ & 0 & $0.0 \%$ \\
\hline \multirow{2}{*}{ Dryness } & No & 27 & $77.1 \%$ & 23 & $65.7 \%$ \\
\hline & Yes & 8 & $22.9 \%$ & 12 & $34.3 \%$ \\
\hline \multirow{2}{*}{ Crusting } & No & 32 & $91.4 \%$ & 27 & $77.1 \%$ \\
\hline & Yes & 3 & $8.6 \%$ & 8 & $22.9 \%$ \\
\hline \multirow{3}{*}{ Bad taste } & No & 35 & $100.0 \%$ & 29 & $82.9 \%$ \\
\hline & Yes & 0 & $0.0 \%$ & 6 & $17.1 \%$ \\
\hline & Yes & 4 & $11.4 \%$ & 5 & $14.3 \%$ \\
\hline
\end{tabular}

A study done by Okubo $\mathrm{K}$ et al, comparing these two drugs in patients who had allergy to cedar pollens, conducted on 640 patients could not establish any superiority between the two intranasal sprays. They also suggested that the once-daily administration of Fluticasone Furoate, compared with the twice-daily administration of Fluticasone Propionate, will be more convenient for patients because there is no need to take the drug as often as before improving drug compliance. ${ }^{8}$
In a study by Valotis A et al, Fluticasone Furoate was shown to have a very fast and extensive association with the human lung glucocorticoid receptor, with a relative receptor affinity significantly higher than for any other glucocorticoid, including Fluticasone Propionate. ${ }^{9}$

Other studies using human lung epithelial cells showed that FF causes rapid translocation of glucocorticoid receptor into the nucleus and exhibits approximately two 
times greater affinity for these cells compared with FP. In addition, no instability or chemical modification of FF was observed in lung tissue. ${ }^{10}$

This advantage of Fluticasone Furoate may contribute to a highly efficacious profile as a topical treatment for Allergic Rhinitis and support the results of this study.

In our study patients have complained about dryness and crusting following the use of intranasal steroid sprays. This is expected as part of the treatment is to reduce the rhinorrhea associated with allergic rhinitis. Some research has to go into developing a compound to enhance the emollient properties so as to reduce these symptoms, though only a handful of patients may develop these complaints.

Patients on Fluticasone Propionate have exclusively complained of a bad after taste after delivering the intranasal spray. This has got to do with the chemical properties of the drug giving it a very distinct after taste which is not appreciated by some patients. Again these issues are not present with Fluticasone Furoate. ${ }^{11}$

The Japanese study also confirms the presence of pain and they have associated the pain with the delivery mechanism and the invasiveness of the nozzle of the spray. In our study, a small percentage of patients on the both the intranasal steroid spray complained of pain on delivery of the drug. We believe that pump of the metered spray is quite strong making the sprayed drug hit the sensitive mucosa lining the nasal cavity causing this pain. We tend to concur with other studies which say that a smaller nozzle and a side actuation system that is available with certain brands can solve this issues. ${ }^{8}$

\section{CONCLUSION}

In our study we found that once daily metered spray of Fluticasone Furoate was as good as or even better than twice daily administered Fluticasone Propionate nasal spray. Patient symptom relief was significant with both the intranasal steroid sprays and achieved excellent control of symptoms. Both the drugs were well tolerated indicating their usefulness in the management of Allergic Rhinitis.

Funding: No funding sources Conflict of interest: None declared

Ethical approval: The study was approved by the Institutional Ethics Committee

\section{REFERENCES}

1. Scadding G, Durham S. Allergic Rhinitis: Scott Browns Otolaryngology Head and Neck Surgery. London: Arnold H. 2008;2(7):1387.

2. Bousquet $J$, van Cauwenberge $P$, Khaltaev $N$. Allergic rhinitis and its impact on asthma. Journal Of Allergy and Clinical Immunology. 2001;108:S147-334.

3. van Cauwenberge $P$, Bachert C, Passalacqa G. Consensus statement on the treatment of allergic rhinitis. European Academy of Allergology and Clinical Immunology. Allergy. 2000;55:116 -34.

4. Prasad R, Kumar R. Allergy situation in India: What is being done? Indian Journal of Chest Diseases and Allied Sciences. 2013;55:7-8.

5. Okubo K, Nakashima M, Miyake N. Comparison of fluticasone furoate and fluticasone propionate for the treatment of Japanese cedar pollinosis: Allergy and Asthma Proceedings. 2009;30(1):84-94.

6. Yadav J, Verma A, Singh J. Study on Nasal Mucous Clearance in Patients of Perennial Allergic Rhinitis: Indian Journal of Allergy, Asthma and Immunology. 2003;17(2):89-91.

7. Okuda M. Grading the severity of allergic rhinitis for treatment strategy and drug study purposes. Current Allergy and Asthma Reports. 2001;1:23541.

8. Okubo K, Nakashima M, Miyake N, Komatsubara M, Okuda M. Comparison of fluticasone furoate and fluticasone propionate for the treatment of Japanese cedar pollinosis. Allergy and Asthma Proceedings. 2009;84(1):84-94.

9. Valotis A, Hogger P. Human receptor kinetics and lung tissue retention of the enhanced-affinity glucocorticoid fluticasone furoate. Respiratory Research. 2007;8:54.

10. Sorbera LA, Serradell N, Bolo SJ. Fluticasone furoate. Drugs of the Future. 2007;32:12-6.

11. Meltzer EO, Stahlman JE, Leflein J. Preferences of adult patients with allergic rhinitis for the sensory attributes of fluticasone furoate versus fluticasone propionate nasal sprays: A randomized, multicenter, double-blind, single-dose, crossover study. Clinical Therapeutics. 2009;30:271-79.

Cite this article as: Nambiar V, Rai S, Somayaji GKS. Fluticasone furoate verses fluticasone propionate: a comparative study by assessment of nasal mucociliary clearance time on patients with allergic rhinitis. Int J Otorhinolaryngol Head Neck Surg 2016;2:35-9. 